Chukwu, A. G.

\title{
An Experimental Investigation of the Effects of Cuttings Size on Mud Rheology.
}

\author{
chukwug@tonciaenergy.com \\ Department of Petroleum and Gas Engineering \\ University of Port Harcourt, Choba, Port Harcourt. \\ This article is covered and protected by copyright law and all rights reserved exclusively by the \\ Centre for Petroleum, Pollution Control and Corrosion Studies. \\ (CEFPACS) Consulting Limited. \\ Electronic copies available to authorised users.
}

The link to this publication is https://ajoeer.org.ng/otn/ajoeer/qtr-2/2020/07.pdf 


\title{
An Experimental Investigation of the Effects of Cuttings Size on Mud Rheology
}

\author{
Chukwu A. G, Kpea-ue M. L, and Nwankwo I. S. \\ Department of Petroleum and Gas Engineering \\ University of Port Harcourt \\ chukwug@tonciaenergy.com; marvinlezor@yahoo.com
}

\begin{abstract}
Effective hole-cleaning is vital for a successful drilling operation and has significant effect on optimizing factors such as penetration rate, bit optimization and well stability. Efficient transportation of drilling cuttings are dependent on factors such as fluid properties and rheology, cuttings size and shape, fluid velocity, cuttings concentration, cuttings transport velocity and rate of penetration. This experimental work examined the effects of cutting sizes on drilling fluid rheology. To achieve this, two fresh samples of mud were prepared and the rheological properties were analyzed at different temperature ranges representing the operating conditions of most Niger Delta wells. A mesh analysis was carried on dried fresh drill cuttings from the Anieze North Field and dried cuttings taken from the laboratory and two samples were selected at ASTM\#40 and \#18. $10 \%$ of these cuttings' samples were added to each mud sample and the rheological properties were measured at similar temperature ranges as the original mud samples. The results gotten shows that at the various temperature ranges, mud contamination with smaller drill cuttings size (ASTM \#40=400um) showed a better performance than the larger particles. The mud rheological properties (viscosity, yield point, YP, plastic viscosity, PV and density) measured at different temperatures showed a remarkable non-linear behavior as shown in the results.
\end{abstract}

KEY WORDS: Cuttings Size, Drill Cuttings, Mud Contamination, Mud Rheology, Temperature.

\section{INTRODUCTION}

An achieved success in the lifting of drill cutting from wellbores and freeing a well off the problems of slipping and accumulated cuttings is a priority of all drilling engineers. Hole cleaning efficiency is a determinant to an optimized drilling, completion and production. Effective hole cleaning determines optimizing factors such as penetration rate, bit optimization and well bore stability. According to Majeed et al. (2014), the efficiency of cutting transportation is dependent on many factors such as fluid properties and rheology, cuttings shape and size, fluid velocity, cuttings concentration, cutting transport velocity, rate of penetration and hole geometry,

During Drilling operation, small pieces of rock are crushed as a result of drill bit activities. These crushed rocks (drill cuttings) are carried by the drilling fluid through the annulus to the surface into the mud pit and shale shaker (Bourgoyne et al., 1986). The carrying capacity of the drilling fluid is its ability to transport cuttings to the surface. With the aid of cuttings properties and operational parameters, a prediction of an effective and efficient hole-cleaning is done during the planning and formulation of a mud system.

Poor hole-cleaning is detrimental to the success of the drilling operation. Negative effects such as increase in drilling cost and drilling time elongation are the general effects of 
improper planning, design and implementation of drilling mud and drilled cuttings transport. Additional poor hole-cleaning can also result to the following:

- Increase drilling string torque

- Slow rate of penetration

- $\quad$ High drag (inability to reach target)

- $\quad$ Logging difficulty

- $\quad$ Pipe stocking risk (fishing or loss of hole)

- $\quad$ Challenging problem during cementing

Drilling operations have been found to be an indispensable part of oil and gas exploration and field development. Not only is the presumed economic benefits resulting from exploitation through mitigation of challenges and damages to the targeted zones increased through a welldesigned drilling program but also, the rig time and drilling cost are ultimately reduced.

Onuoha et al (2015) disclosed that it is worthwhile to have a proper understanding of the entire influential parameters that affects drilled cuttings transport and consequently, hole cleaning. Researchers such as Ozbayoglu et al (2004) and Stan et al (2014) revealed that rate of penetration, cuttings size, cutting density, fluid density, effective fluid viscosity, well inclination and pipe eccentricity are factors that affects the cutting carrying capacity of the drilling fluid. Research works to enhance the hole cleaning capacity of the drilling fluids for an effective and economically efficient drilling operation has been consistently witnessed in the oil and gas industry over time, (Cameron, 2001; Ali et al., 2012). In the presence of enormous problems and dangers of cutting transportation associated with the drilling process of a vertical wellbores, lie the financial benefits (Effiong, 2013). This is one of the reasons why investors continue in oil and gas well drilling investment, in spite of the associated risk. Such risk include excessive over-pull on trip, stuck pipe, hole pack off, excessive equivalent circulating density, premature bit wear, formation fracture, decreased penetration rate, and wellbore steering problems, all these can be tackled by an effective cutting transportation and hole cleaning with an increased in drilling fluid flow rate.

Several studies have shown that rheological properties of the circulating fluid affect solids transportation. Ozbayoglu et al. (2004) in their studies concluded that the amount of cuttings that accumulate in horizontal and highly-inclined wellbores is part of the information that is essential for controlling bottom-hole pressure, preventing stuck pipe and minimizing the circulation time for cleaning the wellbore. In the same work, they conducted a dimensional analysis using basic drilling information such as pump rate, fluid densities and viscosity, drilling rate and well bore geometry, to develop three dimensional groups for estimating the size and concentration of deposited cuttings in horizontal and inclined wellbores for a wide range of drilling fluids.

Furthermore, Wang et al, (2013), reported that rheology is related to shear force which mainly suspends and carries cuttings. However, the effect of rheology on cuttings transport depends on flow rate, flow regime and inclination are among others are some rheological factors that affect the transportation of drill cuttings. It is worthy of note that low viscosity drilling fluid is effective to erode cuttings bed, but high viscosity contributes to carrying cuttings.

The diagram in Figure (1) shows the different rheological behavior of several fluids. From the diagram fluids can be rheologically categorized as dilatant fluids, Newtonian fluids, pseudoplastic fluids, real plastic and Bingham fluids. 


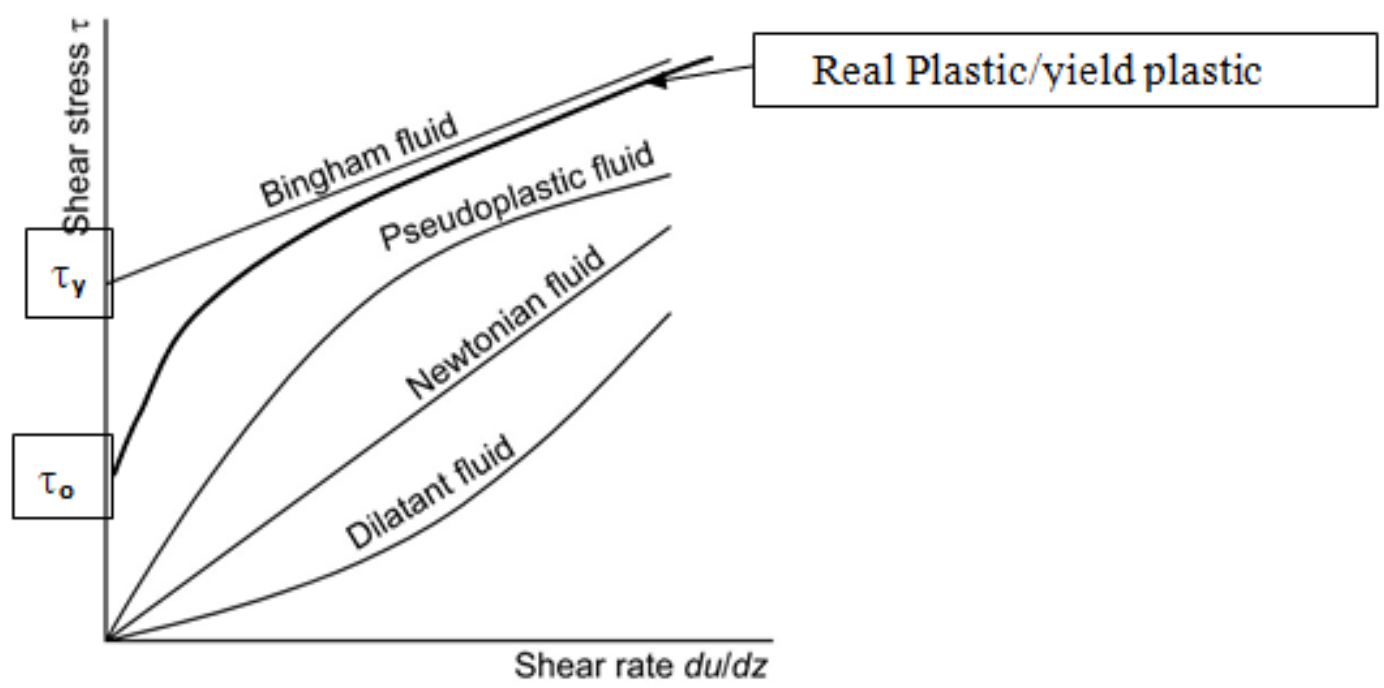

Fig 1: Typical Rheological Behavior of Fluid System (Roosbeh, 2010)

\section{EXPERIMENTAL DESIGN AND METHODS}

In this work, special OBM samples (A \&B) were specially formulated and the rheological properties are simulated at reservoir conditions. Same samples were contaminated with $10 \%$ drill cuttings samples (A \& B) taken from an onsite location and dried laboratory samples. All analysis were made at varying temperature ranges for the determination of mud viscosity, YP, PV,YP/PV and mud density for both ASTM \#40 and ASTM\#18 drill cuttings mesh sizes.

\subsection{Materials and Apparatus}

Table 2: Materials and Apparatus

\begin{tabular}{ll}
\hline $\mathrm{s} / \mathrm{n}$ & Materials/Apparatus \\
\hline 1 & Fan Viscometer \\
2 & Thermo cup \\
3 & Set of sieves \\
4 & Beaker \\
5 & Dryer \\
6 & Mud balance \\
7 & Electronic Balance \\
8 & Mud Stirrer \\
9 & Cleaning brush \\
10 & Timer \\
11 & Thermometer \\
12 & Measuring cylinder \\
13 & Chaterias's flask \\
14 & Water bath \\
15 & Gas Desiccators \\
16 & Mud Samples A \& B \\
16 & Drill Cuttings Samples A \& B \\
\hline
\end{tabular}

\subsection{Experimental Procedures}


2.2.1 Determination of Rheological Properties of Mud Samples (A) and (B)

Fresh Oil-Based mud sample (A) was weighed. $350 \mathrm{ml}$ of the sample was placed in a viscometer thermo cup and the surface was adjusted to the scribed line on the rotor sleeve and heated to a working temperature. The motor was started and readings were taken at 600RPM and 300RPM respectively after a steady value was attained. The above procedures were repeated at speeds 200,100 , $60,30,10$ s and 10mins. A fresh oil based sample (B) was similarly analyzed as sample (A) above. To estimate rheological properties at lower operating temperatures, the samples were cooled in a shower bath containing ice blocks and the above procedures were repeated

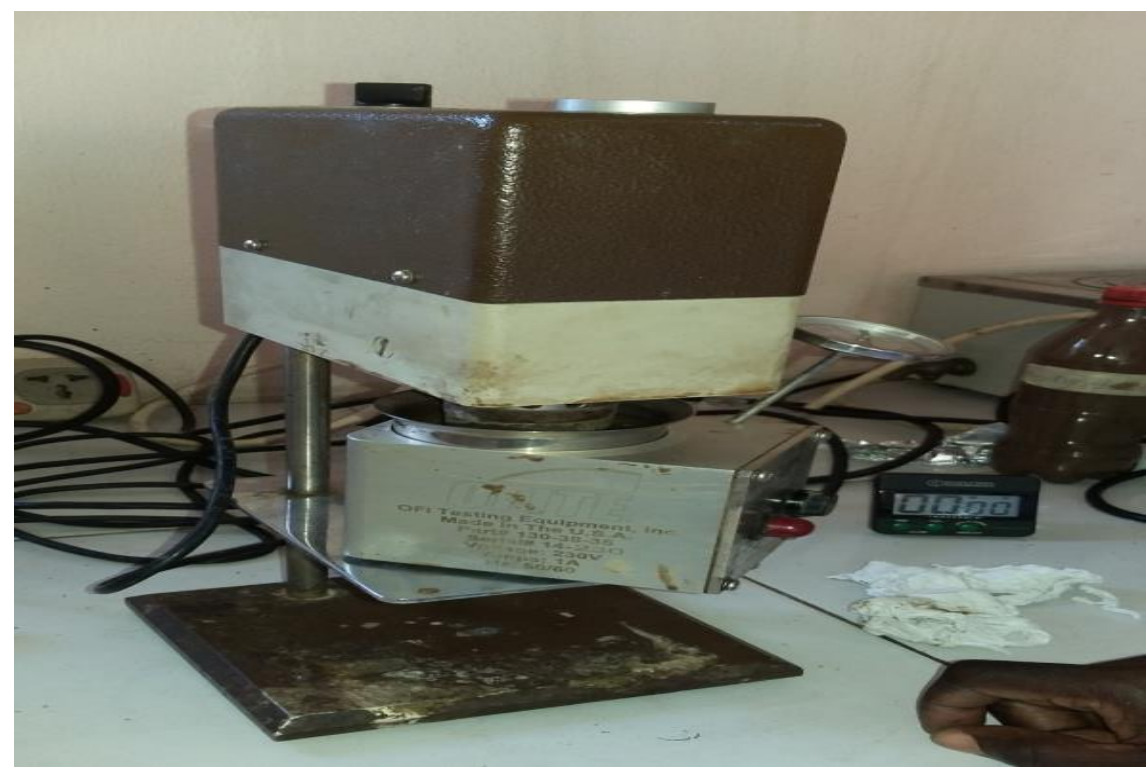

Fig 2: The Fan Viscometer used in the Experiment 


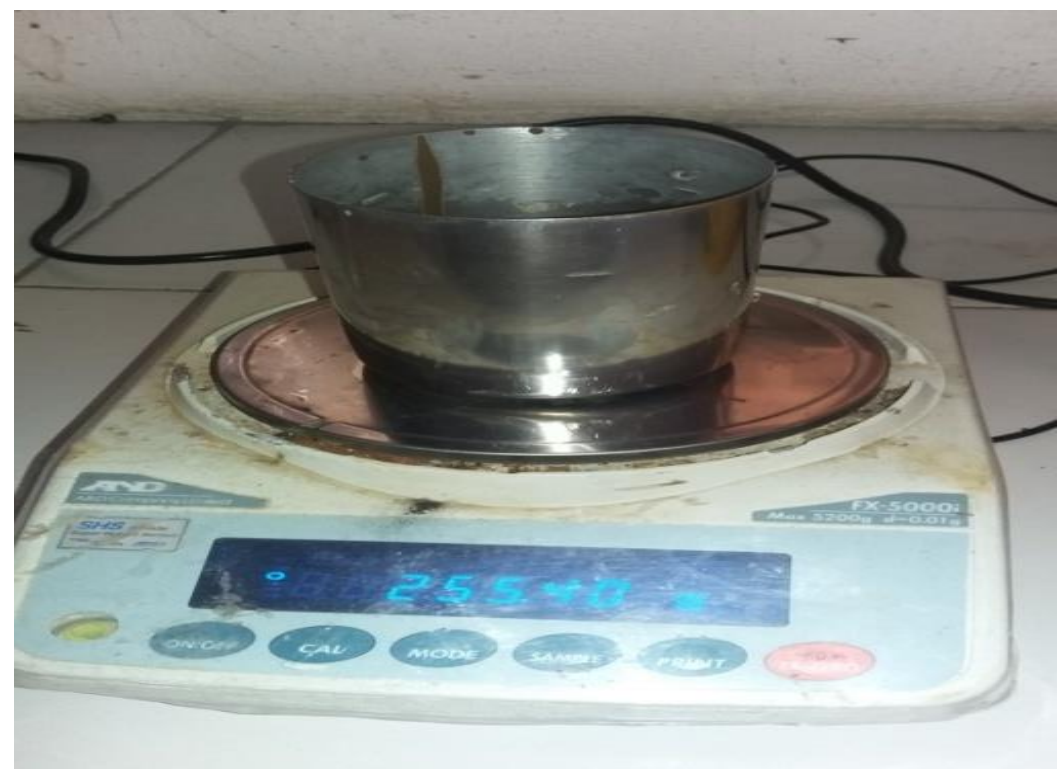

Fig 3: The Electronic Balance and the Thermo Cup used in the Experiment

\subsubsection{Determination of Rheological Properties of Mud Samples (A) \& (B) + Cuttings Samples (A) and (B)}

A fresh sample of drill cuttings gotten from a rig in a Niger Delta and dried drill cuttings taken from the laboratory were collected. The cutting samples were sorted and classified using two sieves -ASTM \#10 (at the top), ASTM \#18, ASTM \#40, ASTM \#140 and ASTM \#200 at bottom. The resulted cuttings sorting were classified similarly in both cases as follows:

- Sample A = 400um (collected at ASTM \#40 sieve)

- Sample B = 1000um (collected at ASTM \#18 sieve)

Based on the above classification, the following test scenarios were analyzed using the procedure in (2.2.1) for the determination of the rheological properties.

Table 3: Laboratory Test Scenarios and Test Sample

\begin{tabular}{cc}
\hline Test Scenario & Sample Specification \\
\hline$\# 1$ & Mud Sample A + Cuttings Sample A \\
\#2 & Mud Sample A + Cuttings Sample B \\
\#3 & Mud Sample B + Cuttings Sample A \\
\#4 & Mud Sample B + Cuttings Sample B \\
\hline
\end{tabular}




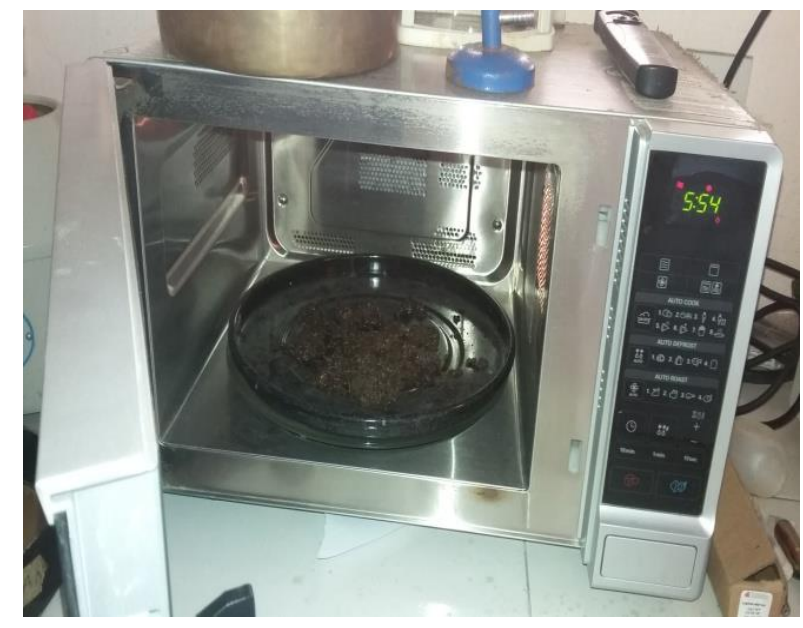

Fig 4: The Electric Drier used in the Experiment

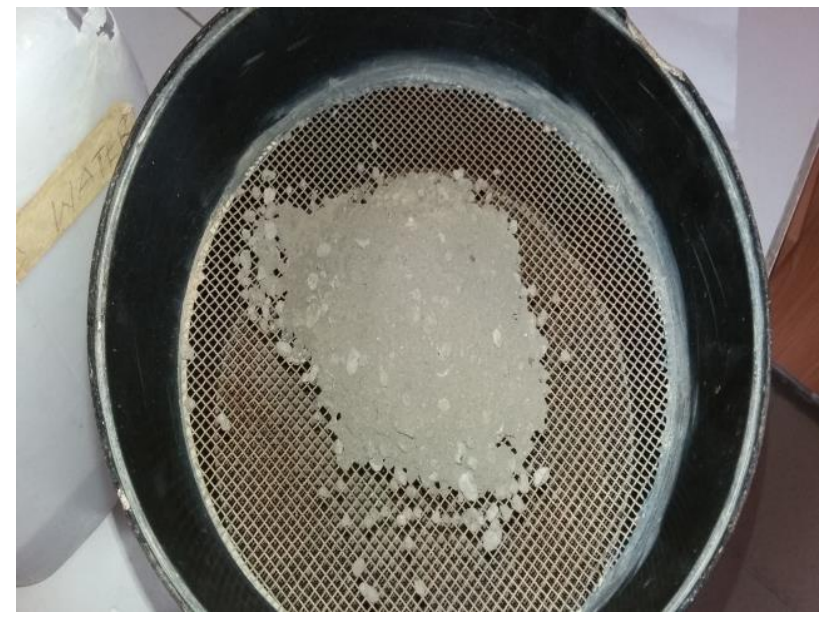

Fig 5: The Wire-mesh (ASTM sieve) used in the Experiment

\section{RESULTS AND DISCUSSION}

The results in Tables 4 and 5 below is a mesh analysis of drill cuttings samples gotten from the Anieze North Field of the Niger Delta. At a Sieve Number \#10, 19.8\% of the fresh drill cuttings sample was retained on the mesh while for the dried laboratory sample $36.5 \%$ was retained. On the hand, at the bottom sieve (\#200), 39\% of fresh drill cuttings sample was retained while $1.21 \%$ of dried laboratory sample was retained. This shows that the Anieze North Field sample is coarser (larger particle size) than the dried laboratory sample. This is evidently shown by the \%Cuttings retained and \%Cuttings passing the sieve (mesh). 
Table 4: Sieve Analysis of Drilled Fresh Drill Cuttings from Anieze North Field

\begin{tabular}{|c|c|c|c|c|c|c|}
\hline $\begin{array}{l}\text { Sieve } \\
\text { Number }\end{array}$ & $\begin{array}{l}\text { Sieve } \\
\text { Diamete } \\
\mathbf{r}(\mu \mathrm{m})\end{array}$ & $\begin{array}{l}\text { Mass of Empty } \\
\text { Sieve (g) }\end{array}$ & $\begin{array}{l}\text { Mass of Sieve + } \\
\text { Cuttings } \\
\text { Retained (g) }\end{array}$ & $\begin{array}{l}\text { Cuttings } \\
\text { Retained } \\
\text { (g) }\end{array}$ & $\begin{array}{l}\% \\
\text { Retaine } \\
\text { d }\end{array}$ & $\begin{array}{l}\% \\
\text { Passing }\end{array}$ \\
\hline 10 & 2,000 & 464.6 & 484.6 & 19.8 & 19.8 & 80.2 \\
\hline $18 *$ & 1,000 & 451.7 & 468.3 & 16.6 & 16.6 & 83.4 \\
\hline $40 *$ & 400 & 436.1 & 451.3 & 15.2 & 15.2 & 84.8 \\
\hline 140 & 100 & 423.3 & 444.9 & 21.6 & 21.6 & 78.4 \\
\hline 200 & 75 & 293.3 & 315.2 & 22.9 & 22.9 & 77.1 \\
\hline Pan & ---- & 230.0 & 233.9 & 3.9 & 39.0 & 61.0 \\
\hline \multicolumn{4}{|c|}{ Total Weight } & 100 & & \\
\hline
\end{tabular}

$\%$ Passing $=100-\Sigma \%$ Retained

Table 5: Sieve Analysis of Dried Drill Cuttings taken from the Laboratory

\begin{tabular}{llcclll}
\hline $\begin{array}{l}\text { Sieve } \\
\text { Number }\end{array}$ & $\begin{array}{l}\text { Sieve } \\
\text { Diameter } \\
(\mu \mathrm{m})\end{array}$ & $\begin{array}{c}\text { Mass of } \\
\text { Empty Sieve } \\
(\mathbf{g})\end{array}$ & $\begin{array}{c}\text { Mass of Sieve } \\
\text { Cuttings Retained } \\
(\mathbf{g})\end{array}$ & $\begin{array}{l}\text { Cuttings } \\
\text { Retained } \\
(\mathbf{g})\end{array}$ & $\begin{array}{l}\text { \% } \\
\text { Retaine } \\
\mathbf{d}\end{array}$ & $\begin{array}{l}\text { \% } \\
\text { Passing }\end{array}$ \\
\hline $\mathbf{1 0}$ & 2,000 & 464.6 & 501.10 & 36.50 & 36.5 & 63.5 \\
$\mathbf{1 8 *}$ & 1,000 & 451.7 & 470.50 & 18.80 & 18.8 & 81.2 \\
$\mathbf{4 0 *}$ & 400 & 436.1 & 454.79 & 18.70 & 18.7 & 81.3 \\
$\mathbf{1 4 0}$ & 100 & 423.3 & 448.00 & 24.72 & 24.7 & 75.3 \\
\hline $\mathbf{2 0 0}$ & 75 & 293.3 & 293.51 & 1.21 & 1.21 & 98.79 \\
\hline Pan & ---- & 230.0 & 230.07 & 0.07 & 0.07 & 99.93 \\
\hline Total Weight & & & 100 & & \\
\hline
\end{tabular}

$\%$ Passing $=100-\Sigma \%$ Retained

\subsection{Effect of Temperature on Mud Rheology}

In this experimental study, the rheological properties of the mud sample at different temperatures are presented. The results in Tables 6-11 clearly illustrate that mud viscosity, plastic viscosity (PV), yield point (YP) and PV/YP ratio exhibit an inverse nonlinear relationship with temperature. The results obtained with mud density shows that within the tested temperature scenarios, the mud density was not affected by temperature. This does not however, imply that mud density is totally independent of temperature. Mud density however, at higher or lower temperatures may show remarkable change depending on the type and composition of the mud. 
Table 6: Rheology of Fresh Oil-Based Mud sample (A) at Different Temperatures

\begin{tabular}{|c|c|c|c|c|c|}
\hline \multirow[t]{2}{*}{ RPM } & \multicolumn{5}{|c|}{ Viscosity Readings (cp) At Different Temperatures } \\
\hline & $80^{\circ} \mathrm{F}$ & $100^{\circ} \mathrm{F}$ & $120^{\circ} \mathrm{F}$ & $150^{\circ} \mathrm{F}$ & $180^{\circ} \mathrm{F}$ \\
\hline 600 & 235 & 223 & 196 & 135 & 103 \\
\hline 300 & 125 & 118 & 103 & 72 & 55 \\
\hline 200 & 86 & 82 & 71 & 52 & 39 \\
\hline 100 & 47 & 46 & 39 & 30 & 24 \\
\hline 60 & 31 & 31 & 25 & 21 & 17 \\
\hline 30 & 19 & 19 & 17 & 15 & 12 \\
\hline 6 & 8 & 8 & 8 & 5 & 4 \\
\hline 3 & 7 & 6 & 7 & 5 & 4 \\
\hline $10 \sec \left(1 b / 100 f^{2}{ }^{2}\right)$ & 7 & 5 & 5 & 3 & 3 \\
\hline $10 \mathrm{~min}\left(1 \mathrm{~b} / 100 \mathrm{ft}^{2}\right)$ & 25 & 23 & 22 & 20 & 18 \\
\hline PV & 110 & 105 & 93 & 63 & 48 \\
\hline$Y P\left(1 b / 100 f^{2}\right)$ & 15 & 13 & 10 & 9 & 7 \\
\hline YP/PV & 0.14 & 0.12 & 0.11 & 0.14 & 0.15 \\
\hline Weight & 10.2 & 10.2 & 10.2 & 10.2 & 10.2 \\
\hline
\end{tabular}

Table 7: Rheology of Fresh Oil-Based Mud (B) at Different Temperatures

\begin{tabular}{|c|c|c|c|c|c|}
\hline RPM & $\begin{array}{l}\text { Visco } \\
\text { RPM }\end{array}$ & Readir & (cp) $\mathbf{A t}$ & fferent & ratures \\
\hline & $80^{\circ} \mathrm{F}$ & $100^{\circ} \mathrm{F}$ & $120^{\circ} \mathrm{F}$ & $150^{\circ} \mathrm{F}$ & $180^{\circ} \mathrm{F}$ \\
\hline 600 & 181 & 166 & 139 & 127 & 99 \\
\hline 300 & 99 & 90 & 75 & 68 & 52 \\
\hline 200 & 68 & 63 & 54 & 48 & 41 \\
\hline 100 & 45 & 42 & 39 & 33 & 28 \\
\hline 60 & 35 & 32 & 30 & 28 & 24 \\
\hline 30 & 28 & 25 & 24 & 22 & 20 \\
\hline 6 & 17 & 18 & 17 & 16 & 14 \\
\hline 3 & 15 & 17 & 15 & 15 & 13 \\
\hline $10 \sec \left(1 b / 100 f^{2}\right)$ & 15 & 19 & 12 & 19 & 15 \\
\hline $10 \mathrm{~min}\left(1 \mathrm{~b} / 100 \mathrm{ft}^{2}\right)$ & 33 & 32 & 30 & 27 & 23 \\
\hline PV & 82 & 76 & 64 & 59 & 47 \\
\hline$Y P\left(1 b / 100 f t^{2}\right)$ & 17 & 14 & 11 & 9 & 5 \\
\hline YP/PV & 0.20 & 0.20 & 0.20 & 0.20 & 0.21 \\
\hline $\begin{array}{l}\text { Mud } \quad \text { Weight } \\
(\text { ppg) }\end{array}$ & 9.1 & 9.1 & 9.1 & 9.1 & 9.1 \\
\hline
\end{tabular}

\subsection{Effect of Cuttings Size on Mud Rheology}

Specially formulated mud samples (400um and 1000um particle sizes) were prepared and analyzed with respect to its rheological properties. The results of each test scenario are presented in Tables 8-11. For both cases of mud samples (A) and (B), the mud mixture containing the 400um cuttings (Drill Cuttings Sample (A)) depicts a better rheological behavior over the tested temperature ranges. This therefore clearly shows that the more the drilling fluids are contaminated by drill cuttings during hole-cleaning, the more the fluid loses its rheological properties necessary to ensure optimized drilling operations. Hence, proper 
mud re-conditioning should always be carried out during mud re-circulation to avoid excessive mud contamination that ultimately alters the rheological properties of such mud.

Table 8: Rheology of Fresh Oil-Based Mud sample (A) + Drilled Cuttings Sample (A) at Different Temperatures

\begin{tabular}{|c|c|c|c|c|c|}
\hline \multirow[t]{2}{*}{ RPM } & \multicolumn{5}{|c|}{ Viscosity Readings (cp) At Different Temperatures } \\
\hline & $80 \mathrm{oF}$ & $100 \mathrm{oF}$ & $120 \mathrm{oF}$ & $150 \mathrm{oF}$ & $180 \mathrm{oF}$ \\
\hline 600 & 220 & 215 & 199 & 167 & 106 \\
\hline 300 & 115 & 112 & 103 & 86 & 54 \\
\hline 200 & 89 & 84 & 74 & 56 & 41 \\
\hline 100 & 52 & 47 & 43 & 34 & 26 \\
\hline 60 & 35 & 31 & 27 & 24 & 18 \\
\hline 30 & 20 & 20 & 18 & 17 & 14 \\
\hline 6 & 8 & 8 & 6 & 6 & 6 \\
\hline 3 & 7 & 6 & 6 & 6 & 6 \\
\hline $10 \sec \left(1 b / 100 f^{2} t^{2}\right)$ & 10 & 7 & 7 & 4 & 4 \\
\hline $10 \mathrm{~min}\left(1 \mathrm{~b} / 100 \mathrm{ft}^{2}\right)$ & 27 & 26 & 26 & 24 & 19 \\
\hline PV & 105 & 103 & 96 & 81 & 52 \\
\hline$Y P\left(1 b / 100 f t^{2}\right)$ & 10 & 9 & 7 & 5 & 2 \\
\hline YP/PV & 0.10 & 0.10 & 0.07 & 0.06 & 0.04 \\
\hline Weight & 10.4 & 10.4 & 10.4 & 10.4 & 10.4 \\
\hline
\end{tabular}

Table 9: Rheology of Fresh Oil-Based Mud (A) + Drilled Cuttings Sample (B) at Different Temperatures

\begin{tabular}{|c|c|c|c|c|c|}
\hline \multirow[t]{2}{*}{ RPM } & \multicolumn{5}{|c|}{ Viscosity Readings (cp) At Different Temperatures } \\
\hline & $80^{\circ} \mathrm{F}$ & $100^{\circ} \mathrm{F}$ & $120^{\circ} \mathrm{F}$ & $150^{\circ} \mathrm{F}$ & $180^{\circ} \mathrm{F}$ \\
\hline 600 & 281 & 255 & 212 & 175 & 132 \\
\hline 300 & 144 & 130 & 108 & 89 & 67 \\
\hline 200 & 100 & 90 & 70 & 64 & 45 \\
\hline 100 & 55 & 50 & 40 & 38 & 30 \\
\hline 60 & 40 & 35 & 28 & 25 & 22 \\
\hline 30 & 25 & 23 & 20 & 19 & 15 \\
\hline 6 & 10 & 9 & 9 & 7 & 5 \\
\hline 3 & 5 & 5 & 3 & 3 & 3 \\
\hline $10 \sec \left(1 b / 100 f^{2}\right)$ & 7 & 7 & 6 & 5 & 3 \\
\hline $10 \mathrm{~min}\left(1 \mathrm{~b} / 100 \mathrm{ft}^{2}\right)$ & 28 & 27 & 26 & 11 & 11 \\
\hline PV & 137 & 125 & 104 & 86 & 65 \\
\hline$Y P\left(1 b / 100 f t^{2}\right)$ & 7 & 5 & 4 & 3 & 2 \\
\hline YP/PV & 0.05 & 0.04 & 0.04 & 0.04 & 0.03 \\
\hline $\begin{array}{l}\text { Mud } \\
\text { (ppg) }\end{array}$ & 10.3 & 10.3 & 10.3 & 10.3 & 10.3 \\
\hline
\end{tabular}

Table 10: Rheology of Fresh Oil-Based Mud (B) + Drilled Cuttings Sample (A) at Different Temperatures 


\begin{tabular}{|c|c|c|c|c|c|}
\hline \multirow[t]{2}{*}{ RPM } & \multicolumn{5}{|c|}{ Viscosity Readings (cp) At Different Temperatures } \\
\hline & $80^{\circ} \mathrm{F}$ & $100^{\circ} \mathrm{F}$ & $120^{\circ} \mathrm{F}$ & $150^{\circ} \mathrm{F}$ & $180^{\circ} \mathrm{F}$ \\
\hline 600 & 177 & 160 & 133 & 114 & 92 \\
\hline 300 & 93 & 84 & 69 & 59 & 47 \\
\hline 200 & 90 & 67 & 59 & 54 & 46 \\
\hline 100 & 60 & 53 & 45 & 40 & 34 \\
\hline 60 & 45 & 40 & 37 & 33 & 27 \\
\hline 30 & 32 & 30 & 27 & 25 & 24 \\
\hline 6 & 20 & 19 & 17 & 17 & 15 \\
\hline 3 & 19 & 17 & 16 & 16 & 14 \\
\hline $10 \sec \left(1 b / 100 f^{2} t^{2}\right)$ & 22 & 22 & 21 & 21 & 17 \\
\hline $10 \min \left(1 \mathrm{~b} / 100 \mathrm{ft}^{2}\right)$ & 39 & 34 & 33 & 29 & 22 \\
\hline PV & 84 & 76 & 64 & 55 & 45 \\
\hline YP (1b/100ft $\left.{ }^{2}\right)$ & 9 & 8 & 5 & 4 & 2 \\
\hline YP/PV & 0.11 & 0.11 & 0.10 & 0.10 & 0.04 \\
\hline $\begin{array}{l}\text { Mud } \\
\text { (ppg) }\end{array}$ & 9.8 & 9.8 & 9.8 & 9.8 & 9.8 \\
\hline
\end{tabular}

Table 11: Rheology of Fresh Oil-Based Mud (B) + Drilled Cuttings Sample (B) at Different Temperatures

\begin{tabular}{|c|c|c|c|c|c|}
\hline \multirow[t]{2}{*}{ RPM } & \multicolumn{5}{|c|}{$\begin{array}{l}\text { Viscosity Readings (cp) At Different Temperatures } \\
\text { RPM }\end{array}$} \\
\hline & $80^{\circ} \mathrm{F}$ & $100^{\circ} \mathrm{F}$ & $120^{\circ} \mathrm{F}$ & $150^{\circ} \mathrm{F}$ & $180^{\circ} \mathrm{F}$ \\
\hline 600 & 174 & 157 & 128 & 112 & 88 \\
\hline 300 & 90 & 81 & 66 & 58 & 45 \\
\hline 200 & 90 & 78 & 64 & 59 & 56 \\
\hline 100 & 55 & 54 & 48 & 42 & 37 \\
\hline 60 & 42 & 41 & 37 & 35 & 30 \\
\hline 30 & 31 & 30 & 29 & 27 & 25 \\
\hline 6 & 20 & 19 & 18 & 19 & 16 \\
\hline 3 & 19 & 17 & 17 & 18 & 15 \\
\hline $10 \sec \left(1 b / 100 f^{2}\right)$ & 24 & 22 & 28 & 21 & 18 \\
\hline $10 \min \left(1 b / 100 f^{2}\right)$ & 39 & 37 & 34 & 28 & 23 \\
\hline PV & 84 & 76 & 62 & 54 & 43 \\
\hline$Y P\left(1 b / 100 f t^{2}\right)$ & 6 & 5 & 4 & 4 & 2 \\
\hline YP/PV & 0.10 & 0.10 & 0.10 & 0.10 & 0.10 \\
\hline Weight & 9.6 & 9.6 & 9.6 & 9.6 & 9.6 \\
\hline
\end{tabular}

Using the YP/PV criteria as given by Wang et al (2013) from collective studies, the mud samples (A) and (B) with cuttings sample (A) will undoubtedly exhibit a better hole cleaning performance than cuttings sample (B). This also clearly illustrates the fact that mud contamination with drill cuttings will directly affect its hole cleaning efficiency and consequently, drilling efficiency. 


\section{CONCLUSION}

In this study, the effect of cuttings size on mud rheology has been investigated using two oil-based mud samples and two drill cuttings sample. The results showed that the interference of drill cuttings with the oil based mud (as used in this study) remarkably alters the rheological properties of the mud. In the test scenarios involving mud sample (A), the effect of drill cuttings size was more pronounced than in mud sample (B). Hence mud composition (additives) also play a significant role in mud rheology during mud contamination by drill cuttings. As a recommendation from the findings in this work, mud treatment and reconditioning can play an optimizing role during drilling operations.

\section{REFERENCES}

Ali, P., Issham, I., Zulkefli, Y., Parham, B. \& Ahmad, S. (2012). Impact of drilling fluid viscosity, velocity and hole inclination on cuttings transport in horizontal and highly deviated wells. $J$. Petrol. Explor. Prod. Technol. Vol 2: Pp149-156.

Bourgoyne. A.T. Jr, Millheim. K.K., Chenevert. M.E. \& Young. F.S. (1986). Applied Drilling Engineering. SPE Textbook Series. Vol. 2, ISBN:978-1-55563-001-0.

Cameron, C. (2001). Drilling Fluids design and Management for Extended Reach Drilling., Paper presented at the SPE/IADC Middle East Drilling Technology Conference. Bahrain.

Francis Effiong. (2013). Experimental Cuttings Transport in Horizontal Wellbore: The Determination of Cuttings Bed Height. Department of Petroleum Engineering and Geophysics, Norwegian University of Science and Technology, Norway.

Majeed, O. A., Faisal, I. K., and Chukwu, G. A., (2014). Cutting Transport Evaluation in Deviated Wells. International conference on Marine and Fresh Water Environment. DOI: 10.13140/2.1.2562.5601. Nigeria.

Onouha. M.D.U., Ismail. I., Piroozian. A., Mamat. N.S. \& Ismail. A.S. (2015). Improving the Cuttings Transport Performance of Water-based Mud Through the use of Polypropylene Beads. pp, 629-634.

Ozbayoglu, M.E., Miska, S.Z. \& Takach, N. (2004). Analysis of the Effects of Major Drilling Parameters on Cuttings Transport Efficiency for High-Angle Wells in Coiled Tubing Drilling Operations. SPE 89334.

Roosbeh Ranjbar. (2010). Cuttings Transport in Inclined and Horizontal Wellbore. Faculty of science and technology. University of Scavanger.

Stan, M. \& Avram, L. (2014). Experimental study on the model of the correlation between the movement of the drilling string with big diameter of drill and effects on the oil rigs. Journal of Petroleum Exploration and Production Technology. Pp1-9.

Wang, k., Yan, T., Sun, X., Shao, S., Luan, S. (2013). Review and Analysis of Cuttings Transport in Complex Structureal Wells. The Open Fuel and Energy Science Journals, College of Petroleum Engineering, Northeast Petroleum University. Daqing 163318, China. 